\title{
Some Strychnos spinosa (Loganiaceae) leaf extracts and fractions have good antimicrobial activities and low cytotoxicities
}

Adamu Imam Isa ${ }^{1,2}$, Maurice Ducret Awouafack ${ }^{1,3}$, Jean Paul Dzoyem ${ }^{1,4^{*}}$, Mohammed Aliyu ${ }^{2}$, Rabiu AbduSsalam Magaji ${ }^{2}$, Joseph Olusegun Ayo ${ }^{5}$ and Jacobus Nicolaas Eloff ${ }^{1}$

\begin{abstract}
Background: Strychnos spinosa Lam. is a deciduous tree used in traditional medicine to treat infectious diseases. This study is designed to determine the antimicrobial, antioxidant and cytotoxic activities of extracts and fractions from leaves of S. spinosa.

Methods: Extracts were obtained by maceration with acetone, methanol and dichloromethane/methanol (1/1) while fractions were prepared by liquid-liquid fractionation of the acetone extract. A broth serial microdilution method with tetrazolium violet as growth indicator was used to determine the minimum inhibitory concentration (MIC) against fungi, Gram-positive and Gram-negative bacteria. The antioxidant activity was determined using free-radical-scavenging assays, and the 3-(4,5-dimethylthiazolyl-2)-2,5-diphenyltetrazolium bromide reduction assay was used to determine cytotoxicity.

Results: Four extracts and five fractions had good to weak antimicrobial activity with MICs ranging from 0.04 to $>1.25 \mathrm{mg} / \mathrm{ml}$ against both fungi and bacteria. The chloroform and ethyl acetate fractions had an MIC of $0.08 \mathrm{mg} / \mathrm{ml}$ against Aspergillus fumigatus. The n-butanol fraction had an MIC of $0.04 \mathrm{mg} / \mathrm{ml}$ against Cryptococcus neoformans. The hexane and chloroform fractions had an MIC of $0.08 \mathrm{mg} / \mathrm{ml}$ against Staphylococcus aureus. The antioxidant activities were much lower than that of the positive controls. Except for the alkaloid extract, all the extracts and fractions had free-radical-scavenging activity $\left(\mathrm{I}_{50}\right.$ ranging from 33.66 to $\left.314.30 \mu \mathrm{g} / \mathrm{ml}\right)$. The cytotoxicity on Vero cells was reasonable to low with $\mathrm{LC}_{50}$ values ranging between 30.56 and $689.39 \mu \mathrm{g} / \mathrm{ml}$.

Conclusion: The acetone extract and the chloroform fraction had the highest antibacterial activity. By solvent-solvent fractionation it was possible to increase the activity against $A$. fumigatus and to decrease the cytotoxicity leading to a potentially useful product to protect animals against aspergillosis. Our results therefore support the use of S. spinosa leaves in traditional medicine to treat infectious diseases.
\end{abstract}

Keywords: Extracts, Different polarity fractions, Antimicrobial, Antioxidant, Cytotoxicity, Selectivity index, Potentizing extracts

\footnotetext{
* Correspondence: jpdzoyem@yahoo.fr

'Phytomedicine Programme, Department of Paraclinical Sciences, Faculty of Veterinary Science, University of Pretoria, Private Bag X04, Onderstepoort 0110 , South Africa

${ }^{4}$ Department of Biochemistry, Faculty of Science, University of Dschang, P.O.

Box 67, Dschang, Cameroon

Full list of author information is available at the end of the article
} 


\section{Background}

The genus Strychnos is a member of the Loganiaceae family comprising about 200 species. Plant species of this genus have been used in folk medicine and in arrow and dart poisons in many parts of the world [1]. Strychnos spinosa Lam. is deciduous shrub or small tree up to $10 \mathrm{~m}$ tall, with a trunk sometimes fluted, up to $25 \mathrm{~cm}$ in diameter, branching from low down. The fruit is generally considered by botanical collectors to be edible, but there are poison-makers who express a contrary opinion and consider the unripe fruit poisonous [2]. It is widely spread in Africa from Senegal through tropical Africa to South Africa. One of its vernacular name given by Hausa people in Nigeria is "Kwokwa or Kokiya" [2]. The plant species is used in traditional medicine for treating snakebite, ulcers, wounds, headache, gastric and intestinal problems, venereal diseases, leprosy, diarrhea, and fever [2]. In Gambia, the plant's leaf decoction with barks powder are used for the treatment of wounds while in Cameroon dried powdered leaves are taken in food for liver damage [2]. The Zulu of South Africa use the green fruits as an antidote to snakebite $[3,4]$. Many pharmacological properties including antiplasmodial [5] antitrypanosomal [6,7] and anthelmintic [8] activities have been reported from $S$. spinosa. Extracts of the stem bark of $S$. spinosa had no activity against bacteria or fungi [9]. The antioxidant activity of the fruit extract of the same species was determined [10]. Several secondary metabolites including triterpenoids, sterols and essential oils [6,7] secoiridoids [11,12], alkaloids [13], and monoterpenes [14] have been indicated or isolated from Strychnos spinosa.

Despite the fact that the leaves of the plant are used in folk medicine in the treatment of several infectious diseases, there is paucity of scientific evidence of the antimicrobial and antioxidant activities, and cytotoxicity of its leaf extract. The aim of this presentation was to determine the antimicrobial and antioxidant activities and also the cytotoxicity of four extracts and five fractions obtained by liquid-liquid extraction from leaves of $S$. spinosa.

\section{Methods}

\section{Plant material}

The leaves of Strychnos spinosa Lam. were collected in January 2013 from Sakara village, Zaria, Nigeria. The plant material was identified by Musa Muhammad a botanist from the herbarium section of the Department of Biological Sciences (Ahmadu Bello University, Zaria) where a voucher specimen (No 900161) was deposited. The collected leaves were dried in a ventilated room free from contamination and then ground to a powder using a Macsalab Mill (Model 2000 LAB Eriez), kept in a glass container and stored in the dark at room temperature $\left(25 \pm 3^{\circ} \mathrm{C}\right)$ before use.

\section{Extraction and liquid-liquid fractionation}

\section{Acetone, methanol and dichloromethane/methanol} extractions

A variation of the method of Suffness \& Douros [15] was used to fractionate the components present in different leaf extracts. The dried leaf powder $(2 \mathrm{~kg})$ was macerated three times in acetone (6 1) [16] to give the acetone extract (AcetE, $75 \mathrm{~g}$ ) after filtration and removal of the solvent in vacuum. The residues were further macerated in methanol (6 l) following the same procedure as described for acetone extraction above to afford the methanol extract (MetE, $119.2 \mathrm{~g}$ ). A part of the dried powdered leaves $(1 \mathrm{~kg})$ was also extracted in a mixture $(1 / 1, \mathrm{v} / \mathrm{v})$ of dichloromethane/methanol (3 l) thrice to give the dichloromethane/methanol extract (DcmMetE, $114 \mathrm{~g}$ ) after filtration and removal of the solvent in vacuum. A part of acetone extract (70 g) was dissolved and fractionated in a mixture $(1 / 1, \mathrm{v} / \mathrm{v})$ of chloroform and water to yield the water and chloroform fractions. $n$-butanol was added to the water fraction to afford the $n$-butanol (nButF, 25.1 g) and water (Wat1, $5 \mathrm{~g}$ ) fractions. The chloroform fraction was concentrated to dryness and dissolved in $10 \%$ water in methanol before the extraction with hexane. The hexane fraction (HexF, 23. $9 \mathrm{~g}$ ) and the residue of 10\% water in methanol were therefore obtained after addition of n-hexane. The proportion of water in methanol was increased to afford 35\% water in methanol component that finally gave chloroform (ChlF, $7.05 \mathrm{~g}$ ) and 35\% water (wat2, $2.8 \mathrm{~g})$ fractions after addition of chloroform. From the comparative TLC, water (Wat1) and 35\% water in methanol (Wat2) fractions were combined into one fraction (WatF, $7.8 \mathrm{~g}$ ).

\section{Alkaloids extraction}

The leaves of $S$. spinosa $(1 \mathrm{~kg})$ were macerated with the mixture (96:3:1, v/v) of EtOAc-EtOH- $\mathrm{NH}_{4} \mathrm{OH}(600 \mathrm{ml})$ and then percolated with EtOAc to give the extract (26 g) after removal of the solvent using rotary evaporator under reduced pressure. The extract was dissolved in EtOAc and extracted with $4 \%$ acetic acid to afford EtOAc fraction (EtAcF, $20.02 \mathrm{~g}$ ). The acidic solution ( $\mathrm{pH} 3-4$ ) was basified to $\mathrm{pH}(8-9)$ with $\mathrm{Na}_{2} \mathrm{CO}_{3}$ and extracted three times with DCM to give crude alkaloids extract (AlkE, $2.8 \mathrm{~g}$ ) after removal of the solvent in vacuum.

\section{Antimicrobial assay}

\section{Microorganisms and inoculum preparation}

Microorganisms used were three Gram-positive bacteria, Bacillius cereus (ATCC 14579), Staphylococcus aureus (ATCC 29213) and Enterococcus faecalis (ATCC 29212), one Gram-negative bacteria, Escherichia coli (ATCC 25922); and four fungi including three yeast Candida albicans, Cryptococcus neoformans (animal isolates) and Candida albicans (ATCC 10231) and one filamentous 
fungi Aspergillus fumigatus. Some fungal strains used were cultured from clinical cases of fungal infectious diseases in animals, before treatment, in the Department of Veterinary Tropical Diseases, Faculty of Veterinary Science. C. albicans was isolated from a Gouldian finch, C. neoformans from a cheetah, while A. fumigatus was isolated from a chicken which suffered from a systemic mycosis.

Bacterial and fungal cultures were taken from $24 \mathrm{~h}$ fresh agar culture plates and inoculated in fresh Sabouraud dextrose broth (SDB) for fungi and Mueller-Hinton broth (MHB) (Fluka, Switzerland) for bacteria, prior to conducting the assay. The turbidity of the microbial suspension was adjusted to a McFarland standard 0.5 equivalent to concentrations of $1-5 \times 10^{8}$ and $1-5 \times 10^{7} \mathrm{cfu} / \mathrm{ml}$ for bacteria and fungi, respectively. The microbial suspensions were further diluted $(1: 100)$ in media to obtain a final inoculum of approximately $1.5 \times 10^{6} \mathrm{cfu} / \mathrm{ml}$ for bacteria and $1.5 \times 10^{5} \mathrm{cfu} / \mathrm{ml}$ for fungi.

\section{Minimun inhibitory concentration determination}

A two-fold serial microdilution method with tetrazolium violet as indicator of microbial growth was used to determine the minimum inhibitory concentration (MIC) values for extracts and fractions against bacteria [16] and fungi [17] as modified by Masoko et al. [18].

A $100 \mu \mathrm{l}(10 \mathrm{mg} / \mathrm{ml})$ of extracts and fractions dissolved in dimethylsulfoxide (DMSO) were serially diluted twofold with sterile distilled water in 96-well microtitre plates and $100 \mu \mathrm{l}$ of freshly prepared microbial culture in MHB or SDB was added to each well. DMSO (5\%) was used as negative control while $(1 \mathrm{mg} / \mathrm{ml})$ gentamicin and amphotericin B were positive controls. The microtitre plates were sealed in plastic bags and incubated for $24 \mathrm{~h}$ at $37^{\circ} \mathrm{C}$. Thereafter, $40 \mu \mathrm{l}$ of $0.2 \mathrm{mg} / \mathrm{ml}$ of $p$-iodonitrotetrazolium violet (INT) was added to each well and microtitre plates were further incubated at $37^{\circ} \mathrm{C}$. Minimal inhibitory concentrations were determined after 1 and $2 \mathrm{~h}$ for bacteria, and 16 and $36 \mathrm{~h}$ for fungi. The MIC was determined as the lowest concentration inhibiting microbial growth, indicated by a decrease in the intensity of the red color of the formazan.

\section{Antioxidant assays}

The antioxidant activities of extracts and fractions from the leaves of $S$. spinosa were determined in term of free-radical scavenging ability using 2,2'-diphenyl-1-picryhydrazyl (DPPH) and 2,2-azino-bis (3-ethylbenzothiazoline-6sulphonic acid) diammonium salt (ABTS).

\section{DPPH assay}

The antioxidant activity was performed as described by $\mathrm{Du}$ Toit et al. [19] with slight modifications. Samples were dissolved in HPLC-grade methanol (Sigma-Aldrich, Germany) and two-fold serially diluted to concentration ranges of 1000 to $7.81 \mu \mathrm{g} / \mathrm{ml}$ for extracts and fractions, and 40 to $0.31 \mu \mathrm{g} / \mathrm{ml}$ for a standard reference L-ascorbic acid (Sigma, Germany). Briefly, $40 \mu \mathrm{l}$ of $(10 \mathrm{mg} / \mathrm{ml})$ of samples were introduced in a 96-well microtitre plates (Bioster, Spain) and two-fold serially diluted in methanol. Thereafter, $160 \mu \mathrm{l}$ of $(3.7 \mathrm{mg} / 100 \mathrm{ml})$ methanolic solution of 2,2-diphenyl-1-picryhydrazyl (DPPH) was introduced in each well and after $30 \mathrm{~min}$ incubation at room temperature in the darkness and the absorbance was measured at $517 \mathrm{~nm}$ using a Multi-Mode Microplate Reader (BioTek, USA). The free-radical-scavenging activity of each sample and the reference standard were determined as percent of the inhibition obtained from the following formula:

$$
\begin{aligned}
& \text { Radical-scavenging capacity }(\%) \\
& \quad=\left[100-\left(\left(\mathrm{Ab}_{\text {sample }}-\mathrm{Ab}_{\text {blank }}\right) / \mathrm{Ab}_{\text {control }}\right) \times 100\right]
\end{aligned}
$$

With $\mathrm{Ab}_{\text {sample }}$ as the absorbance of the extract with $\mathrm{DPPH}, \mathrm{Ab}_{\text {blank }}$ as the absorbance of the extract without $\mathrm{DPPH}$ and $\mathrm{Ab}_{\text {control }}$ as absorbance of methanol and $\mathrm{DPPH}$. The concentration of samples reducing $50 \%$ of free-radical DPPH $\left(\mathrm{IC}_{50}\right)$ was determined by plotting the percentage of inhibition against the sample concentrations. The assay was replicated three times and results are expressed as mean \pm standard deviation.

\section{ABTS assay}

The ABTS radical-scavenging capacity of extracts and fractions was determined using a method of Re et al. [20] with slight modifications. Briefly, the ABTS radical was generated by reacting $7 \mathrm{mM}$ solution of ABTS and $2.45 \mathrm{mM}$ solution of potassium persulfate at room temperature for $12 \mathrm{~h}$. The absorbance of ABTS radical stock solution was adjusted to $7.00 \pm 0.02$ at $734 \mathrm{~nm}$ before used. $40 \mu \mathrm{l}$ of a solution of extracts or fractions dissolved in HPLC-grade methanol (Sigma-Aldrich, Germany) were introduced to microtitre plates and tow-fold serially diluted to concentrations range of 15.62 and $2000 \mu \mathrm{g} / \mathrm{ml}$. Trolox (Sigma, Germany) and L-ascorbic acid (Sigma, Germany) were prepared in concentrations ranging from 200 to $1.56 \mu \mathrm{g} / \mathrm{ml}$. Thereafter, $160 \mu \mathrm{l}$ of ABTS solution was added to wells (except the blank) and the absorbance was measured at $734 \mathrm{~nm}$ after $6 \mathrm{~min}$ incubation at room temperature. Trolox and ascorbic acid were used as positive controls, methanol as negative control and extracts or fractions without ABTS as blank. Percentage of $\mathrm{ABTS} \bullet+$ inhibition and $\mathrm{IC}_{50}$ were calculated as reported above for DPPH assay. 


\section{Cytotoxicity assay}

The cytotoxicity of the acetone extracts and fractions against Vero monkey kidney cells was assessed by the MTT reduction assay as previously described [21] with slight modifications. Cells were seeded at a density of $1 \times 10^{5}$ cells $/ \mathrm{ml}(100 \mu \mathrm{l})$ in 96 -well microtitre plates and incubated at $37^{\circ} \mathrm{C}$ and $5 \% \mathrm{CO}_{2}$ in a humidified environment. After $24 \mathrm{~h}$ incubation, samples $(100 \mu \mathrm{l})$ at varying final concentrations were added to the wells containing cells. Doxorubicin was used as a positive reference. A suitable blank control with equivalent concentrations of acetone was also included and the plates were further incubated for $48 \mathrm{~h}$ in a $\mathrm{CO}_{2}$ incubator. Thereafter, the medium in each well was aspirated from the cells, which were then washed with PBS, and finally fresh medium $(200 \mu \mathrm{l})$ was added to each well. Then, $30 \mu \mathrm{l}$ of MTT $(5 \mathrm{mg} / \mathrm{ml}$ in PBS) was added to each well and the plates were incubated at $37^{\circ} \mathrm{C}$ for $4 \mathrm{~h}$. The medium was aspirated from the wells and DMSO was added to solubilize the formed formazan crystals. The absorbance was measured on a BioTek Synergy microplate reader at $570 \mathrm{~nm}$. Cell growth inhibition for each extract was expressed in terms of $\mathrm{LC}_{50}$ values, defined as the concentration that caused $50 \%$ of inhibition of cell viability. The selectivity index (SI) values were calculated by dividing cytotoxicity $\mathrm{LC}_{50}$ values by the MIC values $\left(\mathrm{SI}=\mathrm{LC}_{50}\right.$ / $\mathrm{MIC})$. Tests were carried out in quadruplicate and each experiment was repeated thrice.

\section{Statistical analysis}

All experiments were conducted in triplicate and values expressed as mean \pm standard deviation. Differences between values were assessed for significance using analysis of variance and results were compared using the Fisher's least significant difference (LSD) at 5\% significance level.

\section{Results and discussion \\ Extraction yield}

Dried powdered leaves of Strychnos spinosa were extracted with acetone, methanol, mixture (v/v) of dichloromethane/ methanol (1/1) and alkaloids extraction procedure to afford extracts (AcetE, MetE, DcmMetE and AlkE) with yields of $3.7,11.9,11.0$, and $0.28 \%$, respectively.

\section{Antimicrobial activities}

Antimicrobial of leaf extracts and fractions of S. spinosa were determined against four fungi and four bacteria and the results are given as minimum inhibitory concentrations (MIC) and total activity in Tables 1 and 2. Many authors classified the antimicrobial activity of plant extracts and fractions to be significant if the MIC is $0.1 \mathrm{mg} / \mathrm{ml}$ or lower, moderate if $0.1<\mathrm{MIC} \leq 0.625 \mathrm{mg} / \mathrm{ml}$ and weak if $\mathrm{MIC}>0.625 \mathrm{mg} / \mathrm{ml}[22,23]$. Based on these criteria, the test samples had significant to weak antimicrobial activity with MICs ranging from 0.04 to $>1.25 \mathrm{mg} / \mathrm{ml}$ against both fungi and bacteria (Table 1).

Table 1 Minimun inhibitory concentration (MIC in $\mathrm{mg} / \mathrm{ml}$ ) of extracts and fractions from S. spinosa against fungi and bacteria

\begin{tabular}{|c|c|c|c|c|c|c|c|c|c|c|c|c|c|c|c|c|}
\hline \multirow{3}{*}{ Samples } & \multicolumn{8}{|c|}{ Fungi $^{a}$} & \multicolumn{8}{|c|}{ Bacteria $^{b}$} \\
\hline & \multicolumn{2}{|c|}{ C. $a$} & \multicolumn{2}{|c|}{ C.A } & \multicolumn{2}{|c|}{ A.f } & \multicolumn{2}{|c|}{ C. $n^{c}$} & \multicolumn{2}{|c|}{ S.a } & \multicolumn{2}{|c|}{ B.C } & \multicolumn{2}{|c|}{ E.f } & \multicolumn{2}{|c|}{ E.c } \\
\hline & $16 \mathrm{~h}$ & $24 \mathrm{~h}$ & $16 \mathrm{~h}$ & $24 \mathrm{~h}$ & $16 \mathrm{~h}$ & $24 \mathrm{~h}$ & $24 \mathrm{~h}$ & $36 \mathrm{~h}$ & $1 \mathrm{~h}$ & $2 \mathrm{~h}$ & $1 \mathrm{~h}$ & $2 \mathrm{~h}$ & $1 \mathrm{~h}$ & $2 \mathrm{~h}$ & $1 \mathrm{~h}$ & $2 \mathrm{~h}$ \\
\hline \multicolumn{17}{|l|}{ Extracts $^{d}$} \\
\hline AcetE & $>1.25$ & $>1.25$ & $>1.25$ & $>1.25$ & 1.25 & $>1.25$ & 0.63 & 0.63 & 0.16 & 0.16 & 0.32 & 0.32 & 0.16 & 0.16 & 0.32 & 1.25 \\
\hline MetE & $>1.25$ & $>1.25$ & $>1.25$ & $>1.25$ & 1.25 & 1.25 & 0.63 & 0.63 & $>1.25$ & $>1.25$ & $>1.25$ & $>1.25$ & $>1.25$ & $>1.25$ & 0.63 & 0.63 \\
\hline DcmMetE & $>1.25$ & $>1.25$ & $>1.25$ & $>1.25$ & 1.25 & 1.25 & 0.16 & 0.16 & 0.63 & 0.63 & $>1.25$ & $>1.25$ & 0.63 & 0.63 & 0.63 & 0.63 \\
\hline AlkE & $>1.25$ & $>1.25$ & $>1.25$ & $>1.25$ & $>1.25$ & $>1.25$ & 0.32 & 0.32 & 0.16 & 0.16 & 1.25 & $>1.25$ & 0.32 & 0.32 & 0.16 & 1.25 \\
\hline \multicolumn{17}{|l|}{ Fractions $^{\mathrm{e}}$} \\
\hline HexF & 1.25 & 1.25 & 0.63 & 0.63 & $>1.25$ & $>1.25$ & 0.32 & 1.25 & 0.08 & 0.08 & 0.63 & 1.25 & 0.32 & 0.32 & 0.08 & 1.25 \\
\hline ChIF & 0.16 & 0.16 & 0.63 & 0.63 & 0.08 & 0.08 & 0.32 & 1.25 & 0.08 & 0.08 & 0.63 & 0.63 & 0.16 & 0.16 & 0.16 & 0.32 \\
\hline EtAcF & 0.63 & 0.63 & 0.16 & 0.16 & 0.08 & 0.08 & 0.32 & 1.25 & 0.16 & 0.16 & 0.63 & 1.25 & 0.16 & 0.32 & 0.16 & 1.25 \\
\hline nBuF & $>1.25$ & $>1.25$ & $>1.25$ & $>1.25$ & 1.25 & 1.25 & 0.04 & 1.25 & 0.08 & 0.16 & 0.63 & 0.63 & 1.25 & 1.25 & 0.63 & 0.63 \\
\hline WatF & $>1.25$ & $>1.25$ & $>1.25$ & $>1.25$ & 1.25 & 1.25 & 0.63 & $>1.25$ & $>1.25$ & $>1.25$ & $>1.25$ & $>1.25$ & $>1.25$ & $>1.25$ & 1.25 & $>1.25$ \\
\hline \multicolumn{17}{|l|}{ Controls $^{f}$} \\
\hline Amp B & 16 & 16 & 8 & 8 & 16 & 16 & $>250$ & $>250$ & - & - & - & - & - & - & - & - \\
\hline Gen & - & - & - & - & - & - & - & - & 0.78 & 0.78 & 0.39 & 0.39 & 1.56 & 1.56 & 0.39 & 0.39 \\
\hline
\end{tabular}

a) C.a: Candida albicans(Isolate); C.A: Candida albicans (ATCC strain); C.n: Cryptococcus neoformans; A.f: Aspergillus fumigatus, b) E.c: Escherichia coli; E.f: Enterococcus faecalis; S.a: Staphylococcus aureus; B.c: Bacillus cereus, c) with this microorganism litle reaction was observed after $16 \mathrm{~h}$ and MIC were recorded after $24 \mathrm{~h}$ and $36 \mathrm{~h}$, d) AcetE: Acetone Extract, MetE: Methanol extract, DcmMetE: Dichloromethane/methanol extract, AlkE: Alkaloids extract, ${ }^{\text {e) }}$ HexF: $n$-hexane fraction, ChIF: Chloroform fraction, EtAcF: Ethyl acetate fraction, nBuF: n-Butanol fraction, WatF: Water fraction, ${ }^{\text {f) }} \mathrm{Amp}$ B: Amphotericin B (in $\mu \mathrm{g} / \mathrm{ml}$ ), Gen: Gentamicin (in $\mu \mathrm{g} / \mathrm{ml}$ ). In bold are values with significant activity. 
Table 2 Total activity in $\mathrm{ml} / \mathrm{g}$ of extracts and fractions from S. spinosa against fungi and bacteria

\begin{tabular}{|c|c|c|c|c|c|c|c|c|c|c|c|c|c|c|c|c|}
\hline \multirow{3}{*}{ Samples } & \multicolumn{8}{|c|}{ Fungi $^{a}$} & \multicolumn{8}{|c|}{ Bacteria $^{\mathbf{b}}$} \\
\hline & \multicolumn{2}{|c|}{ C. $a$} & \multicolumn{2}{|c|}{ C.A } & \multicolumn{2}{|c|}{ A.f } & \multicolumn{2}{|c|}{ C. $n^{c}$} & \multicolumn{2}{|c|}{ S.a } & \multicolumn{2}{|c|}{ B.C } & \multicolumn{2}{|c|}{ E.f } & \multicolumn{2}{|c|}{ E.c } \\
\hline & $16 \mathrm{~h}$ & $24 \mathrm{~h}$ & $16 \mathrm{~h}$ & $24 \mathrm{~h}$ & $16 \mathrm{~h}$ & $24 \mathrm{~h}$ & $24 \mathrm{~h}$ & $36 \mathrm{~h}$ & $1 \mathrm{~h}$ & $2 \mathrm{~h}$ & $1 \mathrm{~h}$ & $2 \mathrm{~h}$ & $1 \mathrm{~h}$ & $2 \mathrm{~h}$ & $1 \mathrm{~h}$ & $2 \mathrm{~h}$ \\
\hline \multicolumn{17}{|l|}{ Extracts $^{d}$} \\
\hline AcetE & 30 & 30 & 30 & 30 & 30 & 30 & 60 & 60 & 234 & 234 & 117 & 117 & 234 & 234 & 117 & 30 \\
\hline MetE & 48 & 48 & 48 & 48 & 48 & 48 & 95 & 95 & 48 & 48 & 48 & 48 & 48 & 48 & 95 & 95 \\
\hline DcmMetE & 46 & 46 & 46 & 46 & 46 & 46 & 356 & 356 & 90 & 90 & 46 & 46 & 90 & 90 & 90 & 90 \\
\hline AlkE & 2 & 2 & 2 & 2 & 2 & 2 & 9 & 9 & 18 & 18 & 2 & 2 & 9 & 9 & 18 & 2 \\
\hline \multicolumn{17}{|l|}{ Fractions $^{\mathrm{e}}$} \\
\hline HexF & 10 & 10 & 19 & 19 & 10 & 10 & 37 & 10 & 149 & 149 & 19 & 10 & 37 & 37 & 149 & 10 \\
\hline ChIF & 23 & 23 & 6 & 6 & 47 & 47 & 12 & 3 & 47 & 47 & 6 & 6 & 23 & 23 & 23 & 12 \\
\hline EtAcF & 32 & 32 & 125 & 125 & 250 & 250 & 63 & 16 & 125 & 125 & 32 & 16 & 125 & 63 & 125 & 16 \\
\hline nBuF & 10 & 10 & 10 & 10 & 10 & 10 & 314 & 10 & 157 & 78 & 20 & 20 & 10 & 10 & 20 & 20 \\
\hline WatF & 3 & 3 & 3 & 3 & 3 & 3 & 6 & 3 & 3 & 3 & 3 & 3 & 3 & 3 & 3 & 3 \\
\hline
\end{tabular}

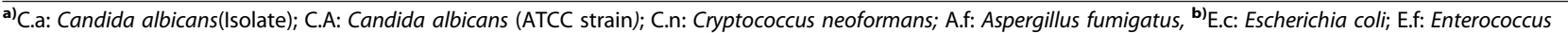
faecalis; S.a: Staphylococcus aureus; B.c: Bacillus cereus, ${ }^{c}$ with this microorganism litle reaction was observed after $16 \mathrm{~h}$ and MIC were recorded after $24 \mathrm{~h}$ and $36 \mathrm{~h}$, d) AcetE: Acetone Extract, MetE: Methanol extract, DcmMetE: Dichloromethane/methanol extract, AlkE: Alkaloids extract, e) HexF: n-hexane fraction, ChIF: Chloroform fraction, EtAcF: Ethyl acetate fraction, nBuF: n-Butanol fraction, WatF: Water fraction. In bold are values with significant activity.

All the extracts had moderate activity against $C$. neoformans with MICs ranging from 0.16 to $0.63 \mathrm{mg} / \mathrm{ml}$. The other fungi were more resistant to extracts with MICs 1.25 or $>1.25 \mathrm{mg} / \mathrm{ml}$. The chloroform and ethyl acetate fractions had significant activities against $A$. fumigatus with $\mathrm{MIC} 0.08 \mathrm{mg} / \mathrm{ml}$ in both cases and were reasonably active against the two strains of Candida (MICs 0.16 and $0.63 \mathrm{mg} / \mathrm{ml}$ ). The n-butanol fraction had good activity against C. neoformans (MIC $0.04 \mathrm{mg} / \mathrm{ml}$ ) after $24 \mathrm{~h}$ of incubation and weak activity against other fungi (MICs 1.25 or $>1.25 \mathrm{mg} / \mathrm{ml}$ ). The hexane fraction had moderate activity against $C$. albicans ATCC strains (MIC $0.63 \mathrm{mg} / \mathrm{ml}$ ) and weak activity against $C$. albicans isolate (MIC $1.25 \mathrm{mg} / \mathrm{ml}$ ) and A. fumigatus (MIC $>1.25 \mathrm{mg} / \mathrm{ml}$ ). Apart from $C$. neoformans (MIC $0.63 \mathrm{mg} / \mathrm{ml}$ after $24 \mathrm{~h}$ of incubation), all the fungi were relatively more resistant to the water fraction with MICs 1.25 or $>1.25 \mathrm{mg} / \mathrm{ml}$.

Most extracts had moderate antibacterial activity with MICs ranging from 0.16 to $0.63 \mathrm{mg} / \mathrm{ml}$. Apart from $E$. coli with MIC value of $1.25 \mathrm{mg} / \mathrm{ml}$ after $2 \mathrm{~h}$ of incubation, the acetone extract had moderate activity against S. aureus (MIC $0.16 \mathrm{mg} / \mathrm{ml})$, B. cereus $(0.32 \mathrm{mg} / \mathrm{ml}), E$. faecalis (MIC 0.16), and E. coli (MIC $0.32 \mathrm{mg} / \mathrm{ml}$ after $1 \mathrm{~h}$ of incubation). The alkaloid extract had moderate activity against $S$. aureus and E. faecalis with MICs of 0.16 and $0.32 \mathrm{mg} / \mathrm{ml}$, respectively. Apart from B. cereus (MIC $>1.25 \mathrm{mg} / \mathrm{ml}$ ), the dichloromethane/methanol extract had moderate activity against all the bacteria with MICs $0.63 \mathrm{mg} / \mathrm{ml}$ in all cases. The hexane and chloroform fractions had significant antibacterial activity against $S$. aureus with an MIC of $0.08 \mathrm{mg} / \mathrm{ml}$ in both cases and moderate activity against most of bacteria (MICs 0.16 $0.63 \mathrm{mg} / \mathrm{ml}$ ). Good activity was obtained after $1 \mathrm{~h}$ of incubation (MIC $0.08 \mathrm{mg} / \mathrm{ml}$ ) with the n-butanol fraction against $S$. aureus and the hexane fraction against $E$. coli. The water fraction had weak antibacterial activity against all the bacteria (MICs $1.25 \mathrm{mg} / \mathrm{ml}$ or greater).

The acetone extract had the highest antibacterial activity (average MIC $0.36 \mathrm{mg} / \mathrm{ml}$ ) while fungi were resistant to all extracts (average MICs $1.09 \mathrm{mg} / \mathrm{ml}$ or greater). These results are similar to those found by previous authors $[24,25]$. The chloroform fraction had the highest antibacterial activity (average MIC $0.28 \mathrm{mg} / \mathrm{ml}$ ) amongst all the fractions, followed by the hexane and ethyl acetate fractions (average MICs 0.50 and $0.51 \mathrm{mg} / \mathrm{ml}$, respectively). These results confirm a statement that the intermediate polarity compounds usually have the highest antimicrobial activity found with many different plant species [26]. The chloroform and the ethyl acetate fractions had most antifungal activity with average MIC of $0.29 \mathrm{mg} / \mathrm{ml}$ in both cases, followed by the hexane fraction with average MIC of $0.94 \mathrm{mg} / \mathrm{ml}$.

All the fractions had fungistatic effect against $C$. neoformans while most of the extracts were bactericidal based on the difference in MIC after different time of incubation. Some bacteriostatic effects were observed for acetone and alkaloid extracts against E. coli, and some fractions such as n-butanol against $S$. aureus, hexane against $B$. cereus and $E$. coli, chloroform against $E$. coli, and ethyl acetate against B. cereus, E. faecalis and E. coli.

The total activity was obtained to quantify the antimicrobial activity by dividing the mass of extract or fraction from $1 \mathrm{~g}$ of the plant material with the MIC value [22]. The acetone extract had the highest antibacterial activity with an average total activity of $165 \mathrm{ml} / \mathrm{g}$. The ethyl acetate fraction had highest antifungal activity with 
Table 3 Antioxidant activities of extracts and fractions from S. spinosa

\begin{tabular}{|c|c|c|}
\hline \multirow[t]{2}{*}{ Samples } & \multicolumn{2}{|l|}{$I C_{50}(\mu \mathrm{g} / \mathrm{ml})$} \\
\hline & DPPH & ABTS \\
\hline \multicolumn{3}{|l|}{ Extracts $^{a}$} \\
\hline AcetE & $95.42 \pm 0.04^{\mathrm{a}}$ & $112.20 \pm 0.01^{a}$ \\
\hline MetE & $36.56 \pm 0.02^{b}$ & $62.74 \pm 0.01^{b}$ \\
\hline DcmMetE & $59.13 \pm 0.02^{c}$ & $150.41 \pm 0.02^{c}$ \\
\hline AlkE & -c) & - \\
\hline \multicolumn{3}{|l|}{ Fractions $^{\mathrm{b}}$} \\
\hline HexF & $203.78 \pm 0.03^{d}$ & $314.30 \pm 0.04^{d}$ \\
\hline ChIF & $230.15 \pm 0.04^{e}$ & $249.82 \pm 0.02^{\mathrm{e}}$ \\
\hline EtAcF & $117.77 \pm 0.04^{f}$ & $249.33 \pm 0.03^{e}$ \\
\hline nBuF & $42.07 \pm 0.03^{9}$ & $74.23 \pm 0.03^{f}$ \\
\hline WatF & $33.66 \pm 0.04^{h}$ & $65.02 \pm 0.03^{9}$ \\
\hline \multicolumn{3}{|l|}{ Controls } \\
\hline L-Ascorbic acid & $4.65 \pm 0.02^{i}$ & $2.26 \pm 0.04^{h}$ \\
\hline Trolox & $9.71 \pm 0.04^{j}$ & $16.46 \pm 0.02^{i}$ \\
\hline
\end{tabular}

average total activity of $125.30 \mathrm{ml} / \mathrm{g}$ on fungi. The dichloromethane/methanol extract had a total activity of $356 \mathrm{ml} / \mathrm{g}$ against C. neoformans, this implies that $1 \mathrm{~g}$ of this extract can be diluted to $356 \mathrm{ml}$ and still inhibits the growth of $C$. neoformans [23,22]. The MeOH extract from the stem bark of $S$. spinosa was previously investigated and had no antimicrobial activity against C. albicans, $S$. aureus, B. cereus and E. coli [9], this can be explained the fact that acetone dissolves many hydrophilic and lipophylic components from the plants and furthermore substantiate the acetone as the best extractant to be used for the screening of antimicrobial from plant extracts [16].

\section{Antioxidant activities}

Antioxidant activities of different extracts and fractions from the leaves of S. spinosa were determined using freeradical-scavenging DPPH and ABTS and results are presented in Table 3. In all cases the antioxidant activity was much lower than that of the positive controls. Apart from the alkaloid extract, all the test samples had DPPH and ABTS-radical-scavenging activity with $\mathrm{IC}_{50}$ ranging from 33.66 to $230.15 \mu \mathrm{g} / \mathrm{ml}$, and 62.74 to $314.30 \mu \mathrm{g} / \mathrm{ml}$, respectively. The most actives being the water fraction $\left(\mathrm{IC}_{50} 33.66\right.$ and $65.02 \mu \mathrm{g} / \mathrm{ml}$ ), methanol extract $\left(\mathrm{IC}_{50} 36.56,62.74 \mu \mathrm{g} / \mathrm{ml}\right)$, and $n$-butanol fraction ( $\left.\mathrm{IC}_{50} 42.07,74.23 \mu \mathrm{g} / \mathrm{ml}\right)$. Hexane, chloroform and ethyl acetate fractions had the lowest antioxidant activity with $\mathrm{IC}_{50}$ ranging from 117.77 to $314.30 \mu \mathrm{g} / \mathrm{ml}$. Even though, the activity displayed by all the samples was significantly weak compare to ascorbic acid and trolox $(\mathrm{p}<0.05)$. However, the antioxidant activity of the $\mathrm{MeOH}$ fruits extract of S. spinosa was reported and the free-radical depletion was attributed not only to phenolic contents but also to the presence of traces of vitamin $C$ in the extract [10].

Table 4 Cytotoxicity of extracts and fractions from S. spinosa, and their selectivity index (SI)

\begin{tabular}{|c|c|c|c|c|c|c|c|c|c|}
\hline \multirow[t]{2}{*}{ Samples } & \multirow[t]{2}{*}{ Cytotoxicity (LC50, $\mu \mathrm{g} / \mathrm{ml})$} & \multicolumn{8}{|c|}{ Selectivity index $(\mathrm{SI})^{*}$} \\
\hline & & C.a & C.A & A.f & C.n & S.a & B.C & E.f & E.c \\
\hline \multicolumn{10}{|l|}{ Extracts } \\
\hline AcetE & $30.56 \pm 0.00^{\mathrm{a}}$ & $<0.02$ & $<0.02$ & 0.02 & 0.05 & 0.19 & 0.1 & 0.19 & $0.04^{* *}$ \\
\hline MetE & $361.48 \pm 0.02^{b}$ & $<0.30$ & $<0.30$ & 0.3 & 0.57 & $<0.30$ & $<0.30$ & $<0.30$ & 0.57 \\
\hline DcmMetE & $38.38 \pm 0.00^{c}$ & $<0.03$ & $<0.03$ & 0.03 & 0.24 & 0.06 & $<0.03$ & 0.06 & 0.06 \\
\hline AlkE & $141.54 \pm 0.00^{d}$ & $<0.11$ & $<0.11$ & $<0.11$ & 0.44 & 0.88 & 0.11 & 0.44 & $0.20^{* *}$ \\
\hline \multicolumn{10}{|l|}{ Fractions } \\
\hline HexF & $71.28 \pm 0.01^{e}$ & 0.06 & 0.11 & $<0.06$ & $0.09^{* *}$ & 0.9 & $0.08^{* *}$ & 0.22 & $0.11^{* *}$ \\
\hline ChIF & $67.20 \pm 0.00^{f}$ & 0.42 & 0.11 & 0.84 & $0.09^{* *}$ & 0.84 & 0.11 & 0.42 & $0.28^{* *}$ \\
\hline EtAcF & $479.44 \pm 0.07^{9}$ & 0.76 & 3 & 6 & $0.61^{* *}$ & 0.76 & $0.51^{* *}$ & $0.20^{* *}$ & $0.68^{* *}$ \\
\hline nBuF & $50.49 \pm 0.01^{\mathrm{h}}$ & $<0.04$ & $<0.04$ & 0.04 & $0.08^{* *}$ & $0.42^{* *}$ & 0.08 & 0.04 & 0.08 \\
\hline WatF & $689.39 \pm 0.00^{i}$ & $<0.55$ & $<0.55$ & 0.55 & $0.73^{* *}$ & $<0.55$ & $<0.55$ & $<0.55$ & 0.55 \\
\hline
\end{tabular}

Control

Dox 


\section{Cytotoxicity}

The cytotoxicity of extracts and fractions was determined on monkey kidney Vero cells in vitro by means of the MTT (3-(4,5-dimethylythiazol-2-yl)-2,5-diphenyl-2H-tetrazolium hydrobromide) assay and results are reported in Table 4 together with selectivity indices. All the test samples had $\mathrm{LC}_{50}$ values ranging between 30.56 and $689.39 \mu \mathrm{g} / \mathrm{ml}$. The water fraction was the least toxic extract or fraction followed by ethyl acetate fraction, methanol extract and alkaloid extract with $\mathrm{LC}_{50}$ values of 689.39 , 479.44, $361.48,141.54 \mu \mathrm{g} / \mathrm{ml}$, respectively. The acetone and dichloromethane/methanol extracts had lowest $\mathrm{LC}_{50}$ values (30.56 and $38.38 \mu \mathrm{g} / \mathrm{ml}$ ) but theirtoxicity was significantly low $(\mathrm{p}<0.05)$ compared to the reference standard doxorubicin $\left(\mathrm{LC}_{50} 2.59 \mu \mathrm{g} / \mathrm{ml}\right)$.

The selectivity index of each extract or fraction on each microorganism was calculated bydividing the $\mathrm{LC}_{50}$ by MIC value. It is generally considered that the ratio for a good therapeutic index for a remedy or drug should be $>10$, which is a cut-off point ensuring that overdose does not put the life of the patient in danger [27]. The acetone extract had the lowest selectivity index against Candida $(<0.02)$. The cytotoxicity of the $\mathrm{MeOH}$ extract from seeds of $S$. nuxvomica was reported with $\mathrm{IC}_{50}$ value of $18134 \mu \mathrm{g} / \mathrm{ml}$ on MCF-7 cancer cell line while no $\mathrm{IC}_{50}$ value was found on Vero cell [28]. The highest selectivity index was obtained for the ethyl acetate fraction against $A$. fumigatus (6.00). These results show that by manipulation of extracts the toxicity can be decreased and/or the efficacy can be increased. It appears that the ethyl acetate fraction has the potential to be used to combat aspergillosis in poultry as was found for an extract of Loxostylus alata [29].

\section{Conclusion}

The results obtained support the use of S. spinosa in traditional medicine for the treatment of infectious diseases. We are currently busy in isolating and characterizing the constituents responsible for the antimicrobial activity from the most active fractions.

\section{Competing interests}

The authors declare that they have no competing interests.

\section{Authors' contribution}

All, MDA and JPD carried out the experiments and wrote the manuscript. MA, RAM, JOA and JNE supervised the work, corrected the manuscript and provided the facilities for the study. All the authors read and approved the final manuscript.

\section{Acknowledgements}

A.I.I is grateful to the Nigerian Tertiary Education Training Fund (TETFund) through Ahmadu Bello University Academic Unit for supporting the work in this paper. M.D.A and J.P.D received Postdoctoral Fellowships from the University of Pretoria to work in the Phytomedicine Programme, Department of Paraclinical Sciences, Faculty of Veterinary Science.

\section{Author details}

'Phytomedicine Programme, Department of Paraclinical Sciences, Faculty of Veterinary Science, University of Pretoria, Private Bag X04, Onderstepoort 0110, South Africa. ${ }^{2}$ Department of Human Physiology, Faculty of Medicine, Ahmadu Bello University, Zaria, Nigeria. ${ }^{3}$ Laboratory of Natural Products Chemistry, Department of Chemistry, Faculty of Science, University of Dschang, P.O. Box 67, Dschang, Cameroon. ${ }^{4}$ Department of Biochemistry, Faculty of Science, University of Dschang, P.O. Box 67, Dschang, Cameroon. ${ }^{5}$ Department of Physiology, Faculty of Veterinary Medicine, Ahmadu Bello University, Zaria 81001, Nigeria.

Received: 3 September 2014 Accepted: 21 November 2014 Published: 27 November 2014

\section{References}

1. Thongphasuk P, Suttisri R, Bavovada R, Verpoorte R: Alkaloids and a pimarane diterpenoid from Strychnos vanprukii. Phytochemistry 2003, 64(4):897-901.

2. Neuwinger HD: African Ethnobotany Poisons and Drugs: Chemistry, Pharmacology, Toxicology. London: Chapman \& Hall; 1996.

3. Hedberg I, Hedberg O, Madati PJ, Mshigeni KE, Mshiu EN, Samuelsson G: Inventory of plants used in traditional medicine in Tanzania II. Plants of the families Dilleniaceae-Opiliaceae. J Ethnopharmacol 1983, 9(1):105-127.

4. Mors WB, Do Nascimento MC, Pereira BMR, Pereira NA: Plant natural products active against snake bite - the molecular approach. Phytochemistry 2000, 55(6):627-642.

5. Bero J, Ganfon H, Jonville MC, Frédérich M, Gbaguidi F, DeMol P, Moudachirou M, Quetin-Leclereq J: In vitro antiplasmodial activity of plants used in Benin in traditional medicine to treat malaria. J Ethnopharmacol 2009, 122(3):439-444.

6. Hoet S, Pieters L, Muccioli GG, Habib-Jiwan JL, Opperdoes FR, Quetin-Leclercq J: Antitrypanosomal activity of triterpenoids and sterols from the leaves of Strychnos spinosa and related compounds. J Nat Prod 2007, 70(8):1360-1363.

7. Hoet S, Stévigny C, Hérent M-C, Quetin-Leclercq J: Antitrypanosomal compounds from the leaf essential oil of Strychnos spinosa. Planta Med 2006, 72(5):480-482.

8. Waterman C, Smith RA, Pontiggia L, DerMarderosian A: Anthelmintic screening of Sub-Saharan African plants used in traditional medicine. J Ethnopharmacol 2010, 127(3):755-759.

9. Kubmarawa D, Ajoku GA, Enwerem NM, Okorie DA: Preliminary phytochemical and antimicrobial screening of 50 medicinal plants from Nigeria. Afr J Biotechnol 2007, 6(14):1690-1696.

10. Nhukarume L, Chikwambi Z, Muchuweti M, Chipurura B: Phenolic content and antioxidant capacities of Parinari curatelifolia, Strychnos spinosa and Adansonia digitata. J Food Biochem 2010, 34(s1):207-221.

11. Itoh A, Oya N, Kawaguchi E, Nishio S, Nishio S, Tanaka Y, Kawachi E, Akita T, Nishi T, Tanahashi T: Secoiridoid glucosides from Strychnos spinosa. J Nat Prod 2005, 68(9):1434-1436.

12. Msonthi JD, Galeffi C, Nicoletti M, Messana I, Marini-Bettolo GB: Kingiside aglucone, a natural secoiridoid from unripe fruits of Strychnos spinosa. Phytochemistry 1985, 24(4):771-772.

13. Ohri FC, Verpoorte R, Baerheim-Svendsen A: 12-Hydroxy-11-methoxy-diaboline: a new alkaloid from Strychnos spinosa (stem bark). Planta Med 1984, 50(5):446-447.

14. Adesogan EK, Morah FN: Stryspinolactone, an unusual monoterpene lactone from Strychnos Spinosa. Phytochemistry 1981, 20(11):2585-2586.

15. Suffness M, Douros J: Drugs of Plant Origin. Method Cancer Res 1979, 26:73-126.

16. Eloff $\mathrm{JN}$ : Which extractant should be used for the screening and isolation of antimicrobial components from plants? J Ethnopharmacol 1998, 60(1):1-8.

17. Eloff JN: A sensitive and quick microplate method to determine the minimal inhibitory concentration of plant extracts for bacteria. Planta Med 1998, 64(8):711-713.

18. Masoko P, Picard J, Eloff JN: Antifungal activities of six South African Terminalia species (Combretaceae). J Ethnopharmacol 2005, 99(2):301-308.

19. Du Toit R, Volsteedt $Y$, Apostolides Z: Comparison of the antioxidant content of fruits, vegetables and teas measured as vitamin $C$ equivalents. Toxicology 2001, 166(1-2):63-69. 
20. Re R, Pellegrini N, Proteggente A, Pannala A, Yang M, Rice-Evans C: Antioxidant activity applying an improved ABTS radical cation decolorization assay. Free Radic Biol Med 1999, 26(9-10):1231-1237.

21. Mosmann T: Rapid colorimetric assay for cellular growth and survival: application to proliferation and cytotoxicity assays. J Immunol Methods 1983, 65(1-2):55-63.

22. Eloff JN: Quantification the bioactivity of plant extracts during screening and bioassay guided fractionation. Phytomedicine 2004, 11(4):370-371.

23. Kuete V: Potential of Cameroonian plants and derived products against microbial infections: a review. Planta Med 2010, 76(14):1479-1491.

24. Kotze M, Eloff JN: Extraction of antibacterial compounds from Combretum microphyllum (Combretaceae). S Afr J Bot 2002, 68(1):62-67.

25. Eloff JN, Famakin JO, Katerere DRP: Combretum woodii (Combretaceae) leaf extracts have high activity against Gram-negative and Gram-positive bacteria. Afr J Biotechnol 2005, 4(10):1161-1166.

26. Eloff JN, McGaw LJ: Using African plant biodiversity to combat microbial infections. In Novel Plant Bioresources: Applications in Food Medicine and Cosmetics. Edited by Gurib-Fakim A. Ltd: John Wiley and Sons; 2014:163-173.

27. Masevhe NA, Awouafack MD, Ahmed AS, McGaw L, Eloff JN:

Clerodendrumic acid, a new triterpenoid from Clerodendrum glabrum (Verbenaceae), and antimicrobial activities of fractions and constituents. Helv Chim Acta 2013, 96(9):1693-1703.

28. Anajwala CC, Patel RM, Dakhara SL, Jariwala JK: In vitro cytotoxicity study of Agave americana, Strychnos nuxvomica and Areca catechu extracts using MCF-7 cell line. J Adv Pharm Technol Res 2010, 1(2):245-252.

29. Suleiman MM, Duncan JN, Eloff JN, Naidoo V: A controlled study to determine the efficacy of Loxostylis alata (Anacardiaceae) in the treatment of aspergillosis in a chicken (Gallus domesticus) model in comparison to ketoconazole. BMC Vet Res 2012, 8:210.

doi:10.1186/1472-6882-14-456

Cite this article as: Isa et al:: Some Strychnos spinosa (Loganiaceae) leaf extracts and fractions have good antimicrobial activities and low

cytotoxicities. BMC Complementary and Alternative Medicine 2014 14:456.

\section{Submit your next manuscript to BioMed Central and take full advantage of:}

- Convenient online submission

- Thorough peer review

- No space constraints or color figure charges

- Immediate publication on acceptance

- Inclusion in PubMed, CAS, Scopus and Google Scholar

- Research which is freely available for redistribution 